\title{
Microencapsulation of probiotics using sodium alginate
}

\author{
Microencapsulação de probióticos utilizando alginato de sódio
}

\author{
Mariana de Araújo Etchepare ${ }^{\mathrm{I}}$ Juliano Smanioto Barin ${ }^{\mathrm{I}}$ Alexandre José Cichoski \\ Eduardo Jacob-Lopes ${ }^{I}$ Roger Wagner $^{I}$ Leadir Lucy Martins Fries ${ }^{I}$ \\ Cristiano Ragagnin de Menezes $^{I^{*}}$
}

\section{- REVIEW -}

\section{ABSTRACT}

The consumption of probiotics is constantly growing due to the numerous benefits conferred on the health of consumers. In this context, Microencapsulation is a technology that favors the viability of probiotic cultures in food products, mainly by the properties of protection against adverse environmental conditions and controlled release. Currently there are different procedures for microencapsulation using polymers of various types of natural and synthetic origin. The use of sodium alginate polymers is one of the largest potential application in the encapsulation of probiotics because of their versatility, biocompatibility and toxicity exemption. The aim of this review is to present viable encapsulation techniques of probiotics with alginate, emphasizing the internal ionic gelation and external ionic gelation, with the possibility of applying, as well as promising for improving these techniques.

Key words: alginate, controlled release, microencapsulation, probiotics.

RESUMO

O consumo de probióticos está em constante crescimento, devido aos inúmeros beneficios conferidos à saúde dos consumidores. Neste contexto, a microencapsulação é uma tecnologia que favorece a viabilidade das culturas probióticas em produtos alimentícios, principalmente pelas propriedades de proteção contra as condições ambientais adversas e a liberação controlada. Atualmente, existem diversos procedimentos para a microencapsulação, com a utilização de vários tipos de polímeros de origem natural e sintética. $O$ alginato de sódio é um dos polímeros com maior potencial para aplicação na encapsulação de probióticos, devido à sua versatilidade, biocompatibilidade $e$ isenção de toxicidade. O objetivo desta revisão é apresentar técnicas viáveis de encapsulação de probióticos com alginato, enfatizando a gelificação iônica interna e gelificação iônica externa, com a possibilidade de aplicação, bem como as tecnologias promissoras para o melhoramento destas.
Palavras-chave:

alginato, liberação controlada, microencapsulação, probióticos.

\section{INTRODUCTION}

The growing concern of consumers about knowing the characteristics of food led to the development of products that promote health and wellness beyond its nutritional function (TYOPPONEN et al., 2003). Functional foods are all foods or beverages, consumed in the daily diet that can bring particular physiological benefits, due to the presence of physiologically active substances, such as probiotics (RODRÍGUEZ et al., 2007).

The term probiotic refers to live microorganisms that, administered in adequate amounts, confer a health benefit to the host. Bacteria belonging to the Lactobacillus and Bifidobacterium spp. genera are most often used as probiotics supplements, once that they have been isolated from all portions of the gastrointestinal tract of healthy humans (SANDERS, 2003).

A microorganism is considered probiotic if it is a normal resident of the gastrointestinal tract survives the passage through the stomach and maintains the viability and activity in the intestine (COOK et al., 2012). Furthermore, these microorganisms must present good technological properties showing good multiplication in the milk, promoting sensorial properties suitable in the product

IDepartamento de Tecnologia e Ciência dos Alimentos, Centro de Ciências Rurais (CCR), Universidade Federal de Santa Maria (UFSM), Av. Roraima, n 1000, 97105-900, Santa Maria, RS, Brasil. E-mail: cristiano.ufsm@gmail.com. *Corresponding author. Received 06.23.14 Approved 11.29.14 Returned by the author 02.16.15 CR-2014-0938.R2 
and being stable and viable during storage, so they can be manipulated and incorporated in food products without losing the viability that must be at least of $10^{6}-10^{7} \mathrm{CFU} \mathrm{g}^{-1}$ (FAO/OMS, 2001).

So according to these facts, the interest for the addition of probiotic microorganisms in several foods have been growing as a way to increase their nutritional and therapeutic values (O'SULLIVAN, 2005) and these foods with probiotic characteristics has been dominating the industrial marketing of functional foods, booming this market, with real tendency to increase by over $50 \%$ in the coming years (DOHERTY et al., 2012).

The best known examples of probiotic foods are fermented milks and yoghurts (NAGPAL et al., 2007), however, other dairy products such as cheese, ice cream and desserts (OLIVEIRA et al., 2014; LEANDRO, et al., 2013; FERNANDES, et al., 2013) are now being studied. However, there are still several problems regarding the low viability of probiotic bacteria in dairy foods. Some factors including titratable acidity, $\mathrm{pH}$ value and hydrogen peroxide, oxygen concentration, storage temperature, interactions with other microorganisms in the products, and lactic and acetic acid concentrations, has affected the viability of these microorganisms in this type of food (CASTRO-CISLAGHI et al., 2012).

On the other hand, foods that present reduced water activity and low hydrogen potential, also provide unfavorable conditions for their own survival. In these foods, for the incorporation of probiotic bacteria, is necessary the use of technologies that protect the microorganism from the external environment and maintain viability in the product.

In this context, the protection and viability of probiotic cultures during processing, storage and passage of the probiotic product through the gastrointestinal tract can occur by the technique of microencapsulation and immobilization on a variety of substrates, including carbohydrates, proteins, and lipids (SULTANA et al., 2001; CASTRO-CISLAGHI et al., 2012; PEDROSO et al., 2012).

The technique of microencapsulation may be defined as the technology for coating particles or droplets of liquid or gaseous material, forming capsules in miniature, which may release their contents at controlled rates and/or under specific conditions (FÁVARO-TRINDADE et al., 2008).

Microencapsulation of probiotic bacteria has been used in order to protect these organisms from adverse conditions of the digestive tract, such as the bactericidal effect of gastric juice and other acid means, presence of oxygen and freezing temperatures, to increase the stability and maintain the culture viability during the storage of the product (CHAMPAGNE \& FUSTIER, 2007).

In this context, several techniques can be used for the microencapsulation of probiotics, such as Spray-drying, which are generally used as water soluble polymer coating material; Spraycongealing, which uses waxes, fatty acids, soluble and water insoluble polymers, and other monomers as coating material; Fluidizedbed coating/airsuspension, which utilizes soluble and water insoluble polymers, lipids and waxes as a coating material; Coacervation or phase separation technique, which uses encapsulating material as water soluble polymers (SUNNY-ROBERTS \& KNORR, 2009). However, these techniques require the use of high or low temperatures and/or the use of organic solvents, which disadvantages the viability of the probiotic cultures (HEIDEBACH et al., 2012).

Among the most commonly used polymers as encapsulating material, there is the sodium alginate which is capable of forming a highly versatile matrix, biocompatible and non-toxic for the protection of active components, cells and mainly probiotic microorganisms sensible to heat, $\mathrm{pH}$, oxygen, and other factors in which the foods are exposed during its processing and storage (GOH et al., 2012).

Among the various techniques for producing microcapsules is the ionic gelation process that is simple and inexpensive. This technique consists of using a polymer solution that comes in contact with an ionic solution in adequate concentrations which can achieve levels of encapsulation and capsules of different shapes and sizes. This process results in the instantaneous formation of microparticles that encapsulate cells or drugs within a three-dimensional network (VOS et al., 2009).

Therefore, due to the importance of this issue to the area of Food Science and Technology, in this review article, it will be addressed the technological aspects used in the microencapsulation of probiotic cultures using sodium alginate, with emphasis on techniques of internal and external ionic gelation, demonstrating the feasibility of implementation as well as new resources for its improvement.

\section{DEVELOPMENT}

Sodium alginate as the encapsulating agent

Alginate has been used as the encapsulating material due to its ability to absorb water, to be easy manipulated and innocuousness, having also other 
features such as gelling, stabilizing and thickening, reasons which have been of great interest to the food industry (GOH et al., 2012). It is the most polysaccharide used as encapsulating material of lactic acid bacteria, due to ease of handling, non-toxic nature and low cost, besides increasing the viability of these bacteria when exposed to different conditions when are compared with non-encapsulated bacteria (BURGAIN et al., 2011).

This polymer is presented as a food additive in the form of white or yellowish brown powder, tasteless and odorless. It is Consisted mainly by the sodium salt of alginic acid, or that is, a mixture of polyuronic acids composed of residues of D-mannuronic and L-guluronic acid (Figure 1a e 1b) (ROWE et al., 2009).

The microparticles of calcium alginate are generally prepared by two methods: extrusion method by dripping a solution of sodium alginate into a solution of a calcium salt, leading to the phenomenon of external ionic gelation; and the emulsification method, for internal ionic gelation of alginate in a water/oil emulsion (Figure 1c) (GOMBOTZ et al., 1998).

The gelation occurs when it is produced a zone of union between the blocks of acid $\alpha$-Lguluronic $(G)$ of a molecule of alginate that it is physically connected to another block of acid $\alpha$-Lguluronic $(\mathrm{G})$ from another molecule of alginate by calcium ions. The preview of the structure is called the egg box model (Figure 1d) (DRAGET, 2000).

External ionic gelation

The external ionic gelation occurs using the technique of extrusion. In this technique, the microorganisms are added to an alginate solution and are immediately incorporated in the form of droplets in a solution of calcium chloride to hardening (YEO et al., 2001). The interaction of the ions, such as $\mathrm{Ca}^{2+}$, with the carboxyl groups of the polymer chains of the alginate results in the formation of an insoluble gel (SMRDEL et al., 2008).

Particles produced by extrusion typically present diameters ranging from $500 \mu \mathrm{m}$ to $3 \mathrm{~mm}$, and the size of the particles formed is dependent on the size of the diameter of the needle used to drip the solution, the viscosity and concentration of the alginate solution, besides the distance between the syringe and the solution of calcium chloride (BUREY et al., 2008).

On these facts, variants of the method have been developed. Some of these consist in using a pressure system to force the output of the alginate through the pipette, which is consisted of a vibration system to disperse the drops of the end of the pipette to particles of less than $300 \mu \mathrm{m}$ and a method of nebulization which originated particles of less than $1 \mu \mathrm{m}$ (BURGESS \& HICKEY, 1994). In this case, for application in foods, the average diameter of the microparticles, is one of the most important characteristics, since they must be small enough, to avoid a negative sensorial impact, and to acchieve the desired size of approximately $100 \mu \mathrm{m}$ (HEIDEBACH et al., 2012).

\section{Internal ionic gelation}

The internal ionic gelation occurs for the emulsion technique that has been successfully applied in the process of microencapsulation of probiotics (MORTAZAVIAN et al., 2007; MARTIN et al., 2013). It consisted of the emulsion of an alginate solution that forms a discontinuous phase, in a solution of larger volume of vegetable oil, or continuous phase. The hardening of the capsules results from the addition, under magnetic agitation, of a solution of calcium chloride (HEIDEBACH et al., 2012). Subsequently, the gelation is initiated by reducing the $\mathrm{pH}$ by adding an acid solution, which in turn causes the release of calcium ions, allowing the complexation of calcium to the carboxylic groups of the polymer (BUREY et al., 2008).

The microcapsules obtained by emulsion technique are relatively minor when compared with the technique of extrusion, being easier to dimension at industrial terms. The size of the capsules depends on the homogeneity and agitation speed, ranging from $20-25 \mu \mathrm{m}$ to $2 \mathrm{~mm}$ (MORTAZAVIAN et al., 2007).

In terms of costs, this method is more expensive due to the use of vegetable oil in appreciable amounts (MORTAZAVIAN et al., 2007), however, the production of microparticles without the use of organic solvents makes it an increasingly and promising technique of extrusion, particularly for encapsulating drugs, immobilized living cells and to inclusion of compounds of interest in foods (PATIL et al., 2010; KRASAEKOOPT \& WATCHARAPOKA, 2014).

Encapsulation of probiotics using sodium alginate Several in vitro studies demonstrate the advantages of microencapsulation of probiotic using alginate as a coating material. CHANDRANOULI et al. (2004) studied the viability of Lactobacillus acidophilus encapsulated at different concentrations of calcium alginate in concentrations of $0.5,1.8$ and $2 \% \mathrm{w} / \mathrm{v}$, in the presence of gastric juice $(\mathrm{pH} \mathrm{2,0)}$, 


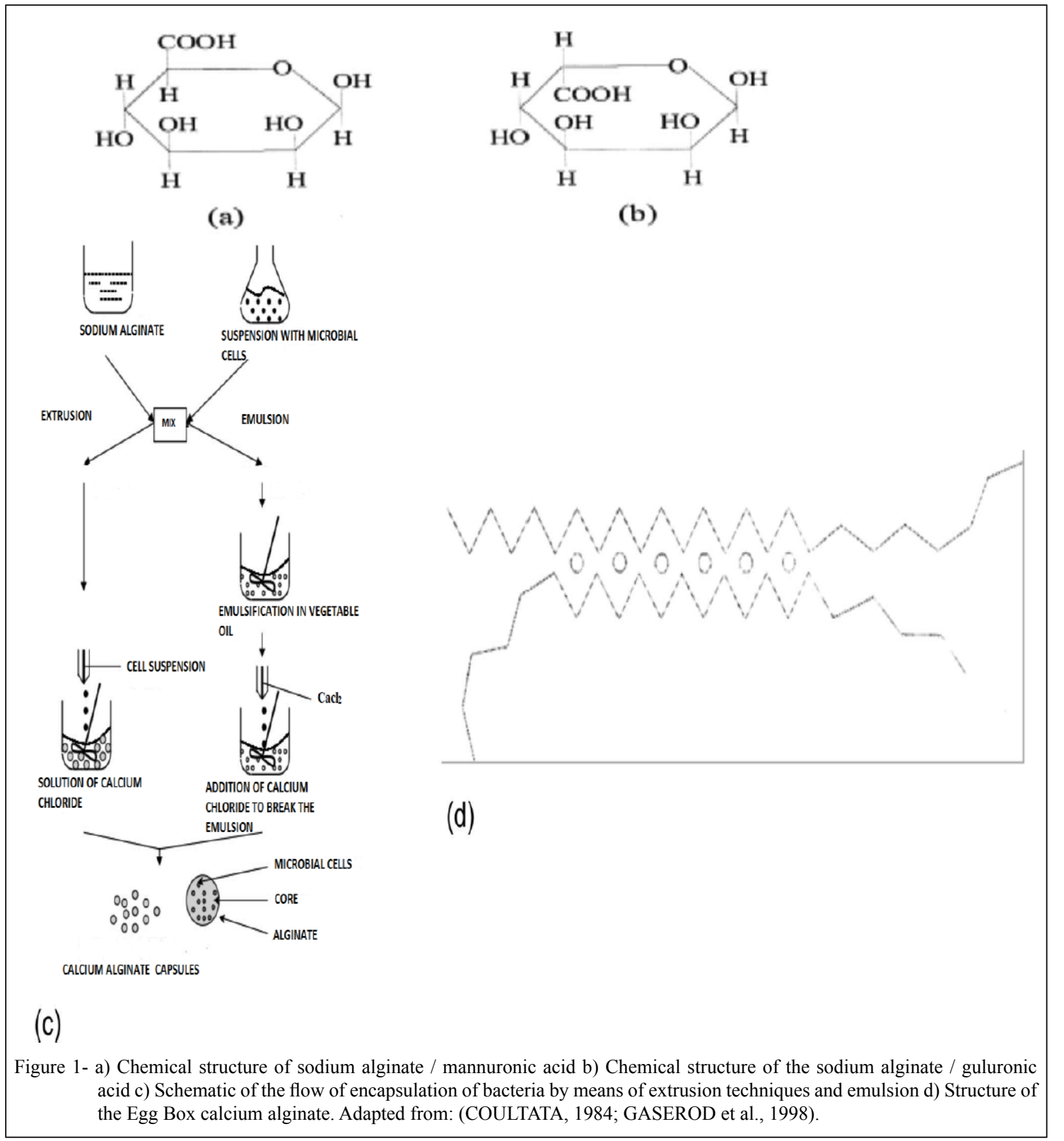

obtaining promising viability values $\left(10^{6} \mathrm{CFU} \mathrm{ml^{-1 }}\right)$, more successfully to $2 \%$ concentration. In the research conducted by KIM et al. (2008) positive results were obtained for Lactobacillus acidophilus ATCC 43121 encapsulated with calcium alginate, by the drip method, during exposure to the in vitro gastrointestinal tract and resistance to the thermal treatment.

Some studies are already analyzing the behavior of probiotic microcapsules in various kinds of foods. KHALIL \& MANSOUR (1998) incorporated bifidobacteria encapsulated with alginate in mayonnaise and evaluated the survival of cells during refrigerated storage at $5^{\circ} \mathrm{C}$ for 12 weeks and also obtained results above $10^{6} \mathrm{CFU}$ $\mathrm{ml}^{-1}$. In another study, OZER et al. (2009) added Lactobacillus acidophilus microencapsulated in $2 \%$ of alginate gel by the extrusion technique in white cheese and analyzed it throughout 90 days of storage, at $4^{\circ} \mathrm{C}$ and obtained the counting above $10^{6} \mathrm{CFU} \mathrm{ml}^{-1}$.

Despite the sodium alginate being suitable for the encapsulation, the gel presents porosity and sensitibility to extreme $\mathrm{pH}$, which can interfere both to the release and to protection of the compounds (MORTAZAVIAN et al., 2007). There are several ways to overcome this obstacle and improve stability of microorganisms as, for example, coating the 
particles with ionic gelling with biopolymers through electrostatic interactions (PATIL et al., 2010) and the addition of prebiotics in the capsule formulation (CHEN et al., 2005).

Improvement of the alginate capsules: electrostatic interaction

The electrostatic interaction occurs between charged biopolymers with opposite charges. In most cases, the systems of biopolymers used include a protein molecule as apositive polyelectrolyte and a polysaccharide molecule as a negative polyelectrolyte (JUN-XIA et al., 2011). In this context, emerged the method called layer-by-layer that was applied to the area of microencapsulation, for the production of multilayer of polyelectrolyte. The technique is based on consecutive adsorption of alternated layers of charged polyelectrolyte positively and negatively on the template particle and has the driving force to electrostatic interaction (KREFT et al., 2007).

Polycations such as chitosan, poly-amino acid (e.g., poly lysine) and the proteins of the milk whey, besides reducing the porosity of gel, form a strong complex with alginates which are stable in the presence of chelating agents of $\mathrm{Ca}^{2+}$ (GOMBOTZ et al., 1998). The association of these compounds with calcium alginate leads to the formation of more stable capsule, allowing the formation of a double wall in the microcapsule (CHÁVARRI et al., 2010).

LEE et al. (2004) investigated the effect of microparticles of alginate coated with three types of chitosans of different molecular weight on the survival of Lactobacillus bulgaricus KFRI 673 in simulated gastric juices, intestinal juices and their stability during the storage at 4 and $22^{\circ} \mathrm{C}$. It was concluded that microencapsulation with alginate and chitosan offers a better coating and a more effective means of viable bacterial delivery to the colon, besides of maintaining survival during the refrigerated storage, especially with chitosan of high molecular weight.

GBASSI et al. (2009) used a milk whey protein to coat the microparticles of alginate containing probiotic cultures of Lactobacillus plantarum. In tests in simulated gastric system, the capsules with coating showed a much more effective protection in the probiotic viability, than the capsules without the coating of milk whey protein, demonstrating that this material is effective for coating microcapsules with the aim of greater cell viability.

Improvement of the alginate: prebiotics addition

The combination of alginate with prebiotics offers an enhanced protection for probiotics in food systems due to the symbiotic relationship (CHEN et al., 2005). This can be explained by the fact that prebiotics form three-dimensional networks of microcrystals which interact together, forming small aggregates that contribute to a better protection of bacterial cells (TÁRREGA et al., 2010).

Prebiotics are defined as non-digestible substances, resistant to hydrolysis in the stomach and small intestine and, therefore, integrate the category of dietary fibers, playing important roles in the nutritional aspect, physiological and immunological, constituting a viable alternative to improve the probiotic activity (NINESS, 1999).

Among the prebiotics used in microencapsulation of probiotics stand out: fructooligosaccharides, inulin and resistant starches(SIRÓ et al., 2008.). In table 1, some of studies are reported for microcapsules produced with sodium alginate combined with other polymers, some being considered prebiotics.

Studies conducted by HOMAYOUNI et al. (2008), demonstrated that a combination of alginate with starch improves the efficiency of different bacterial cells, particularly lactic acid-producing bacteria, due to the production of granules of good prebiotic structure and effect in the microcapsules. MIRZAEI et al. (2012) obtained satisfactory results to produce cheese with Lactobacillus acidophilus using 2\% of sodium alginate and $2 \%$ of resistant starch as encapsulating materials. In this study, the microencapsulation was able to keep the number of probiotic bacteria above the required level therapeutic $\left(>10^{7} \mathrm{CFU} \mathrm{\textrm {g } ^ { - 1 }}\right)$. SATHYABAMA et al. (2014), added probiotics from the chicórea and beet sugar at a ratio of $2 \mathrm{~g}$ per $100 \mathrm{ml}$ of the alginate in the encapsulation of Enterococcus fecium, obtaining higher cell viability in in vitro tests of resistance in simulated gastrointestinal system.

In 2013, MARTIN et al. examined the viability of Lactobacillus fermentum CECT5716 microencapsulated in sodium alginate and sodium alginate combined with starch. The results showed that there was a $3.0 \log$ reduction in the microcapsules of alginate and of only $0.3 \mathrm{log}$ in formulas with alginate and starch.

KRASAEKOOPT \& WATCHARAPOKA (2014) combined both techniques of the capsule improvement to study the effect of galactooligosaccharides and insulin in the survival of Lactobacillus acidophilus and Lactobacillus casei microencapsulated in calcium alginate coated with chitosan in simulated digestive system. The capsules were added to yogurt and fruit juice and obtained the viability assessed during refrigerated storage for 4 weeks. 
Table 1 - Microcapsules produced with sodium alginate combined with other polymers

\begin{tabular}{lll}
\hline Microorganisms & Special treatment & Reference \\
\hline Lactobacillus spp. & Chitosan and Corn starch & IYER \& KAILASAPATHY, (2005) \\
Lactobacillus gasseri e Bifidobacterium bifidum & Chitosan & CHÁVARRI et al. (2010) \\
Lactobacillus casei e Bifidobacterium lactis & Resistant starch & HOMAYOUNI et al. (2008) \\
BAL & Starch & JANKOWSKI et al. (1997) \\
Bifidobacterium animalis subsp. lactis Bb12 & Chitosan-acryl-eze & LISERRE et al. (2007) \\
Bifidobacterium & Poli-L-lisine & CUI et al. (2000) \\
Lactobacillus casei & Starch & CHAN et al. (2011) \\
Lactobacillus casei e Bifidobacterium bifidum & Resistant starch & FAHIMDANESH et al. (2012) \\
Lactobacillus casei & Starch & CHAN et al. (2011) \\
\hline
\end{tabular}

The addition of prebiotics during microencapsulation provided better protection for the probiotic improving the growth of these microorganisms in simulated digestive system and the number of probiotic bacteria were maintained above the minimum recommended therapeutic $\left(10^{7} \mathrm{CFU} \mathrm{g}{ }^{-1}\right)$ over the storage in both products.

\section{CONCLUSION}

The features disclosed by the sodium alginate, as, biocompatibility, biodegradability and non-toxic profile provide the feasibility of this polymer for the use in the microencapsulation of probiotics. The research about the encapsulation of these microorganisms in sodium alginate gel has been promising and this technology has proven to be a viable alternative, maintaining substantially the stability of these bacteria in both storage and passage through the gastrointestinal tract. The inclusion of other adjuvant materials improves the viability of these organisms and makes the technique more efficient, thus demonstrating, the potential use of the polymer for coating probiotics in application in foods.

\section{ACKNOWLEDGEMENTS}

To Conselho Nacional de Desenvolvimento Científico e Tecnológico (CNPq), for the financial support.

\section{REFERENCES}

BUREY, P. et al. Hydrocolloid gel particles, formation, characterization, and application. Critical Reviews in Food Science and Nutrition, v.48, p.361-377, 2008. Available from: $<$ http://dx.doi.org/10.1080/10408390701347801>. Accessed: Jun. 2, 2013. doi:10.1080/10408390701347801.

BURGAIN, J. et al. Encapsulation of probiotic living cells: From laboratory scale to industrial applications. Journal of Food
Engineering, v.104, p.467-483, 2011. Available from: <http:// dx.doi.org/10.1016/j.jfoodeng.2010.12.031>. Accessed: Jun. 2, 2013. doi:10.1016/j.jfoodeng.2010.12.031.

BURGESS, D.J.; HICKEY, A.J. Microsphere technology and applications. Encyclopedia of Pharmaceutical technology, v.10, p.1-29, 1994.

CASTRO-CISLAGHI, F.P. et al. Bifidobacterium Bb-12 microencapsulated by spray drying with whey: Survival under simulated gastrointestinal conditions, tolerance to $\mathrm{NaCl}$, and viability during storage. Journal of Food Engineering, v.113, p.186-193, 2012. Available from: <http://dx.doi.org/doi:10.1016/j. jfoodeng.2012.06.006>. Accessed: Jun. 2, 2013. doi: 10.1016/j. jfoodeng.2012.06.006

CHAMPAGNE, C.P.; FUSTIER, L. Microencapsulation for the improved delivery of bioactive compounds into foods. Current Opinion in Biotechnology, v.18, n.2, p.184-90, 2007. Available from: <http://dx.doi.org/10.1016/j.copbio.2007.03.001>. Accessed: Jun. 2, 2013. doi: 10.1016/j.copbio.2007.03.001.

CHEN, K. et al. Optimization of Incorporated Prebiotics as Coating Materials for Probiotic Microencapsulation. Journal of Food Science V. 70, p. 260-266, 2005. Available from: <http:// dx.doi.org/10.1111/j.1365-2621.2005.tb09981.x>. Accessed: Jun. 2, 2013. doi: 10.1111/j.1365-2621.2005.tb09981.x.

CHANDRANOULI, V. et al. An improved method of microencapsulation and its evaluation to protect Lactobacillus spp. in simulated gastric conditions. Journal of Microbiological Methods, v.56, n.1, p.27-35, 2004. Available from: <http://dx.doi. org/10.1016/j.mimet.2003.09.002>. Accessed: Jun. 2, 2013. doi: 10.1016/j.mimet.2003.09.002.

CHÁVARRI, M. Microencapsulation of a probiotic and prebiotic in alginate-chitosan capsules improves survival in simulated gastro-intestinal conditions. International Journal of Food Microbiology, v.142, p.185-189, 2010. Available from: <http:// dx.doi.org/10.1016/j.ijfoodmicro.2010.06.022>. Accessed: May 4, 2013. doi: 10.1016/j.ijfoodmicro.2010.06.022.

CHEN, K.W. et al. Optimization of incorporated prebiotic as coating materials for probiotics microencapsulation. Journal of Food Science, v.70, p.60-66, 2005. Available from: <http://dx.doi. org/1010.1111/j.1365-2621.2005.tb09981.x>. Accessed: May 4, 2013. doi: 10.1111/j.1365-2621.2005.tb09981.x. 
COOK, M.T. et al. Microencapsulation of probiotics for gastrointestinal delivery. Journal of Controlled Release, v.162, p.56-67, 2012. Available from: <http://dx.doi.org/10.1016/j. jconrel.2012.06.003>. Accessed: Jun. 2, 2013. doi: 10.1016/j. jconrel.2012.06.003.

COULTATA, T.P. Alimentos. Química de sus componentes. Zaragoza (España): Acribia, 1984. 199p.

DRAGET, K. I. Alginates. In: PHILLIPS, G. O.; WILLIAMS, P. A. (Edited) Handbook of hydrocolloids. England: Wood head Publishing Limited, 2000. 948p.

DOHERTY, D. et al. Danone touts yogurt in Asia as Europe tightens ad rules. Euromonitor International, 2012. Available from: <http://www.euromonitor.com/>. Accessed: Jun, 2, 2013.

FAHIMDANESH, M. et al. Effect of microencapsulation plus resistant starch on survival of Lactobacillus casei and Bifidobacterium bifidum in mayonnaise sauce. African Journal of Microbiology Research, v.6, n.40, p.6853-6858, 2012. Available from: < http://dx.doi.org/10.5897/AJMR12.1240>. Accessed: Jun. 2, 2013. doi: 10.5897/AJMR12.1240

FOOD AND AGRICULTURE ORGANIZATION OF THE UNITED NATIONS; WORLD HEALTH ORGANIZATION. Health and nutritional properties of probiotics in food including powder milk with live lactic acid bacteria. 2001 34p. Available from: <ftp://ftp.fao.org/es/esn/food/probioreport en.pdf $>$. Accessed: Jun. 2, 2013. [Report of a Joint FAO/WHO Expert Consultation].

FÁVARO-TRINDADE， C.S. Revisão: microencapsulação de ingredientes alimentícios. Brazilian Journal Food Technology, v.11, n.2, p.103-112, 2008 .

FERNANDES, M.S. et al. On the behavior of Listeria innocua and Lactobacillus acidophilus co-inoculated in a dairy dessert and the potential impacts on food safety and product's functionality. Food Control, v.34, p.331-335, 2013. Available from: <http:// dx.doi.org/10.1016/j.foodcont.2013.04.040>. Accessed: Jun. 2, 2013. doi: 10.1016/j.foodcont.2013.04.040.

GASEROD, O. et al. Microcapsules of alginate-chitosan I: A quantitative study of the interaction between alginate and chitosan. Biomaterials, v.19, n.20, p.1815-1825, 1998. Available from: $<$ http://dx.doi.org/10.1016/s0142-9612(98)00073-8>. Accessed: Jun. 2, 2013. doi: 10.1016/s0142-9612(98)00073-8.

GBASSI, G.K., et al. Microencapsulation of Lactobacillus plantarum spp in an alginate matrix coated with whey proteins. International Journal of Food Microbiology, v.129, p.103105, 2009. Available from: <http://dx.doi.org/10.1016/j. ijfoodmicro.2008.11.012>. Accessed: Jun. 2, 2013. doi: 10.1016/j. ijfoodmicro.2008.11.012.

$\mathrm{GOH}$, C.H. et al. Alginates as a useful natural polymer for microencapsulation and therapeutic applications. Carbohidrate Polymers, v.88, p.1-12, 2012. Available from: <http://dx.doi. org/10.1016/jcarbpol.2011.11.012>. Accessed: Jun. 2, 2013. doi:10.1016/j.carbpol.2011.11.012.

GOMBOTZ, W.R.; WU, S.F. Protein release from alginate. Advanced Drug Delivery Reviews, v.31 p.67-285, 1998. Available from: <http://dx.doi.org/10.1016/j.addr.2012.09.007>. Accessed: Jun. 2, 2013. doi: 10.1016/j.addr.2012.09.007.
HEIDEBACH, T. et al. Microencapsulation of probiotic cell by means of rennet-gelation of milk proteins. Food Hydrocolloids, v.23, p.1670-1677, 2012. Available from: <http://dx.doi. org/10.1016/j.foodhyd.2009.01.006>. Accessed: Jun. 2, 2013. doi: 10.1016/j.foodhyd.2009.01.006.

HOMAYOUNI, A. Effect of microencapsulation and resistant starch on the probiotic survival and sensory properties of synbiotic ice cream. Food Chemistry, v.111, n.1, p.50-55, 2008. Available from: $<$ http://dx.doi.org/10.1016/j.foodchem.2008.03.036>. Accessed: Jun. 2, 2013. doi: 10.1016/j.foodchem.2008.03.036.

JUN-XIA, X. et al. Microencapsulation of sweet orange oil by complex coacervation with soybean protein isolate/gum Arabic. Food Chemistry, v.125, p.1267-1272, 2011. Available from: $<$ http://dx.doi.org/10.1016/j.foodchem.2010.10.063>. Accessed: Jun. 2, 2013. doi: 10.1016/j.foodchem.2010.10.063.

KHALIL, A.H.; MANSOUR, E.H. Alginate encapsulated bifidobacteria survival in mayonnaise. Journal Food Science, v.63, p.702-705, 1998. Available from: <http://dx.doi. org/10.1111/j.1365-2621.1998.tb15817>. Accessed: Jun. 2, 2013. doi: 10.1111/j.1365-2621.1998.tb15817.

KIM, S.J. et al. Effect of microencapsulation on viability and other characteristics in Lactobacillus acidophilus ATCC 43121. LWT Food Science and Technology, v.41, p.493-500, 2008. Available from: <http://dx.doi.org/10.1016/j.lwt.2007.03.025>. Accessed: Jun. 2, 2013. doi: 10.1016/j.lwt.2007.03.025.

KRASAEKOOPT, W.; WATCHARAPOKA, S. Effect of addition of inulin and galactooligosaccharide on the survival of microencapsulated probiotics in alginate beads coated with chitosan in simulated digestive system, yogurt and fruit juice. LWT - Food Science and Technology, v.57, p. 761-766, 2014. Available from: <http://dx.doi.org/10.1016/j.lwt.2014.01.037>. Accessed: Jun. 2, 2013. doi: 10.1016/j.lwt.2014.01.037.

KREFT, O. et al. Shell-in-shell microcapsules: a novel tool for integrated, spatially confined enzymatic reactions. Angewandte Chemie International, v.46, p.5605-5608, 2007. Available from: $<$ http://dx.doi.org/10.1002/anie.200701173>. Accessed: Jun. 2, 2013. doi: $10.1002 /$ anie. 200701173

LEANDRO, E.S. et al. Survival of Lactobacillus delbrueckii UFV $\mathrm{H} 2 \mathrm{~b} 20$ in ice cream produced with different fat levels and after submission to stress acid and bile salts. Journal of functional foods, v.5, p.503-507, 2013. Available from: <http://dx.doi. org/10.1016/j.jff.2012.10.003>. Accessed: Jun. 2, 2013. doi: 10.1016/j.jff.2012.10.003.

LEE, K.Y.; HEO, T.R. Survival of Bifidobacterium longum in calcium alginate beads in simulated gastric juices and bile salt solution. Applied Environmental Microbiology, v.66, p.869-873, 2004. Available from: <http://dx.doi.org/10.1128/ AEM.66.2.869-873.2000>. Accessed: Jun. 2, 2013. doi: 10.1128/ AEM.66.2.869-873.2000

MARTIN, M.J. Effect of unmodified starch on viability of alginateencapsulated Lactobacillus fermentum CECT5716. LWT - Food Science and Technology, v.53, p.480-486, 2013. Available from: $<$ http://dx.doi.org/10.1016/j.lwt.2013.03.019>. Accessed: Jun. 2, 2013. doi: 10.1016/j.lwt.2013.03.019.

MIRZAEI, H. et al. Effect of calcium alginate and resistant starch microencapsulation on the survival rate of Lactobacillus 
acidophilus La5 and sensory properties in Iranian white brined cheese. Food Chemistry, v.132, p.1966-1970, 2012. Available from: $<$ http://dx.doi.org/10.1016/j.foodchem.2011.12.033>. Accessed: Jun. 2, 2013. doi: 10.1016/j.foodchem.2011.12.033.

MORTAZAVIAN, A.M.; SOHRABVANDI, S. Probiotics and food probiotic products: based on dairy probiotic products (Ed. A.M. MORTAZAVIAN). P. 131-169, Iran: Eta Publication, 2007.

NAGPAL, R. et al. Potential of probiotic and prebiotics for symbiotic functional dairy foods: an overview. International Journal of Probiotics and Prebiotics, v.2, p.75-84, 2007.

NINESS, K.R. Inulin and oligofructose: what are they? Journal of Nutrition, v.129, n.7, p.1402-1406, 1999.

OLIVEIRA, M.E.G. et al. Addition of probiotic bacteria in a semihard goat cheese (coalho): Survival to simulated gastrointestinal conditions and inhibitory effect against pathogenic bacteria. Food Research International, v.64, p.241-247, 2014. Available from: $<$ http://dx.doi.org/10.1016/j.foodres.2014.06.032>. Accessed: Jun. 2, 2013. doi: 10.1016/j.foodres.2014.06.032.

O'SULLIVAN, D.J. Primary sources of probiotic cultures. In: I. GOKTEPE, V.K. JUNEJA and M. AHMEDNA (eds). Probiotics in food safety and human health. Boca Raton: Taylor \& Francis, p. $89-105,2005$.

OZER, B. et al. Improving the viability of Bifidobacterium bifidum BB-12 and Lactobacillus acidophilus LA-5 in whitebrined cheese by microencapsulation. International Dairy Journal, v.19, n.1, p.22-29, 2009. Available from: $<$ http://dx.doi. org/10.1016/j.idairyj.2008.07.001>. Accessed: Jun. 2, 2013. doi: 10.1016/j.idairyj.2008.07.001.

PATIL, J.S. et al. Ionotropic gelation and polyelectrolyte complexation: the novel techniques to design hydrogel particulate sustained, modulated drug delivery system: a review. Digest Journal of Nanomaterials and Biostructures, v.5, n.1, p.241-248, 2010.

PEDROSO, D.L et al. Protection of Bifidobacterium lactis and Lactobacillus acidophilus by microencapsulation using spraychilling. International Dairy Journal, v.26. n.2, p. 127-132, 2012. Available from: $<$ http://dx.doi.org/10.1016/j.idairyj.2012.04.008>. Accessed: Jun. 2, 2013. doi: 10.1016/j.idairyj.2012.04.008.

RODRÍGUEZ-HUEZO, M.E et al. Pre-selection of protective colloids for enhanced viability of Bifidobacterium bifidum following spray-drying and storage, and evaluation of aguamiel as thermoprotective prebiotic. Food Research International, v.40, p.1299-1306, 2007. Available from: <http:// dx.doi.org/10.1016/j.foodres.2007.09.001>. Accessed: Jun. 2, 2013. doi: $10.1016 /$ j.foodres.2007.09.001.

ROWE, R. C. Handbook of Pharmaceutical Excipients. 6th edition. 2009 London, UK: Pharmaceutical Press e Washington, DC: American Pharmacists Association. 1064p.

SANDERS, M.E. Probiotics: considerations for human health. Revista de Nutrição, n.61, p.91-99, 2003.
SATHYABAMA, S. et al. Co-encapsulation of probiotics with prebiotics on alginate matrix and its effect on viability in simulated gastric environment. Food Science and Technology, n.57, p.419-425, 2014. Available from: <http://dx.doi.org/10.1026/j. lwt.2013.12.024> Accessed: Jun. 2, 2013. doi: 10.1016/j. lwt.2013.12.024.

SIRÓ, I. et al. Functional food product development marketing and consumer aceptance - a review. Apettite, v. 51, p.456-467, 2008. Available from: <http://dx.doi.org/10.1016/j.appet.2008.05.060>. Accessed: Jun. 2, 2013. doi:10.1016/j.appet.2008.05.060.

SMRDEL, P. et al. Shape optimization and characterization of polysaccharide beads prepared by ionotropic gelation. Journal of Microencapsulation, v.25, n.2, p.90-105, 2008. Available from: $<$ http://dx.doi.org/10.1080/02652040701776109>. Accessed: Jun. 2, 2013. doi: 10.1080/02652040701776109.

SULTANA, K. et al. Encapsulation of probiotic bacteria with alginate-starch and evaluation of survival in simulated gastrointestinal conditions and in yoghurt. International Journal of Food Microbiology, v.62, p.47-55, 2000. Available from: $<$ http://dx.doi.org/10.1016/S0168-1605(00)00380-9>. Accessed: Jun. 2, 2013. doi: 10.1016/S0168-1605(00)00380-9.

SUNNY-ROBERTS, E.O.; KNORR, D. The protective effect of monosodium glutamate on survival of Lactobacillus rhamnosus GG and Lactobacillus rhamnosus E-97800 (E800) strains during spray-drying and storage in trehalosecontaining powders. International Dairy Journal, v.19, p.209-214, 2009. Available from: <http://dx.doi.org/10.1016/j. idairyj.2008.10.008>. Accessed: Jun. 2, 2013. doi: 10.1016/j. idairyj.2008.10.008.

TÁRREGA, A. et al. Effects of blends of short and long-chain inulin on the rheological and sensory properties of prebiotic lowfat custards. LWT- Food Science and Technology, v.43, n.3, p.556-562, 2010. Available from: <http://dx.doi.org/10.1016/j. lwt.2009.10.002>. Accessed: Jun. 2, 2013. doi: 10.1016/j. lwt.2009.10.002.

TYOPPONEN, S. Bioprotectives and probiotics for dry sausages. International Journal Food Microbiology, v.83, p. 233244, 2003. Available from: <http://dx.doi.org/10.1016/S01681605(02)00379-3>. Accessed: Jun. 2, 2013. doi:10.1016/S01681605(02)00379-3

VOS, P. et al. Multiscale requirements for bioencapsulation in medicine and biotechnology. Biomaterials, n.30, p.25592570, 2009. Available from: <http://dx.doi.org/10.1016/j. biomaterials.2009.01.014>. Accessed: Jun. 2, 2013. doi: 10.1016/j. biomaterials.2009.01.014.

YEO, Y. et al. Microencapsulation methods for delivery of protein drugs. Biotechnology and Bioprocess Engineering, v.6, n.4, p.213-230, 2001. Available from: <http://dx.doi. org/10.1007\%2FBF02931982>. Accessed: Jun. 2, 2013. doi:10.1007\%2FBF02931982. 